\title{
Results of Testing Several Potato Varieties (Solanum tuberosum L.) Under The Immature Coffee Plants
}

\author{
Benni Satria, Aprizal Zainal, Ryan Budi Setiawan, Ardi Ardi, Afrima Sari \\ Department of Agrotechnology, Faculty of Agriculture, Andalas University, Padang, West Sumatra, 25163, Indonesia
}

Article Info

\section{Received:}

20 November 2019

Accepted:

27 August 2020

Published:

28 August 2020

Competing Interest:

The authors have declared that no competing interest exists.

\section{Corresponding Author:}

Benni Satria, Department of

Agrotechnology, Faculty of Agriculture, Andalas University, Padang, West Sumatra, 25163, Indonesia

Email:bennisatri@@agr.unand.ac.id

(C) 2020 The Authors. This is an open access article under the CC BY license.

\begin{abstract}
Potatoes have the potential to be developed as a source of carbohydrates in supporting food diversification programs. The number of potato productivity in Indonesia is relatively low. The effort that can be made to increase land productivity is through multiple cropping systems such as intercropping, intermittent intercropping, streak planting, annual intercropping, and agroforestry. It is necessary to use idle land under plantation stands that have not been optimized, in increasing productivity and efficiency of agricultural production systems. This study aims to get the varieties that have the best growth and yields planted under immature coffee stands. This research applies a Single Factorial Experiment in Completely Random Design, where the factor is four levels of potato varieties, Granola (V1), Bliss (V2), Kentang Merah (V3) and Batang Hitam (V4). Observations made include plant height, number of leaves, leaf length, leaf width, tuber length, tuber diameter, weight per tuber, number of tubers/plat, and total tuber by grade tubers (Small, Medium, Large, Very large). Based on the analysis variance of each observation variable shows, there is an effect of the variable observation except the width of the leaves. Granola provides the best response to the growth and yield of potato plants.
\end{abstract}

Keywords : Genetics, Environment, Performance, Yield, Variety 


\section{Introduction}

Potatoes have the potential to be developed as a source of carbohydrates in supporting food diversification programs. According to Hakim (1999), vegetables have high carbohydrate, mineral and vitamin contents, so they can be used as another food source to replace rice, with a taste that is preferred by the public. Utilization of potatoes in Indonesia more as a vegetable and chips. According to Sastrahidayat, 2011 , in addition to being used as a vegetable, potatoes can be treated as an industrial material, such as starch. The number of processed from potatoes resulted in a demand for national potatoes increased.

Based on data from the Ministry of Agriculture (2017) that potato productivity in Indonesia ranges from 15,4 to 18,3 ton/ ha and the production of potato from 2014 to 2017 continues to decrease. An increase in potato production can be by intensification and extensification. One of them is through the intercropping to increase land efficiency. In supporting the success of intercropping, selecting the right varieties especially those that are resistant to shade. Potato varieties widely used in Indonesia include granola, bliss, Batang hitam, and kentang merah (red potatoes). Granola has an oval tuber shape, the surface of the tuber is smooth, and the flesh color is yellow (Sitangga, 2013). Batang Hitam is a variety that originates from Agam, West Sumatra, with the growing age of approximately 100 days. Kentang merah variety is prevalent because of its high complex carbohydrate content.

Elfarinsa et al, (2000) stated that optimizing the use of idle land under the stands of plantation crops can increase the productivity and efficiency of agricultural production systems. According to Pranoto (2012), the agroforestry system can be carried out in the upstream zone of the watershed. Some plants that have the potential to be planted with agroforestry systems are spinach, kale, onions, tomatoes, string beans, corn, and cabbage (Bahrun, 2012). Lack of light received by plants is a significant problem in the area under tree stands. Chozin et al, (2000) state that the value of light intensity is only $50 \%$ under a 3 -year rubber stand. In utilizing land under the stand of plantation crops, it is essential to use superior varieties that can grow and develop well under pressure (Sopandie et al., 2003). So, this study aims to know which one of the best from several potato varieties due to the intercropping.

\section{Materials and Methods}

\section{A. Plant Material and Time of Research}

Research started from May to December 2019 at Alahan Panjang, Solok Regency, West Sumatera. This research applies a Single Factorial Experiment in Completely Random Design, where the factor is four levels of potato varieties, Granola (V1), Bliss (V2),
Kentang Merah (V3) and Batang Hitam (V4), with 3 replications.

\section{B. Experimental Details}

They are planting potato plants between rows of coffee that are nine months old, with an average height of $40 \mathrm{~cm}-100 \mathrm{~cm}$. The spacing between the coffee plants is $3 \mathrm{mx} 4 \mathrm{~m}$, so the land under the coffee stands can develop other suitable plants. The observations of this research also focused on potato plants to obtain potential varieties cultivated under coffee stands. The potato seeds used are the tubers that healthy and resistant to pests and diseases. Planting potatoes by putting potato tubers into the soil with a hole in 10 $\mathrm{cm}$. The maintenance carried out includes watering, weeding, embroidering, controlling pests and diseases, and pruning the stems.

The research activities began by manually cultivating the soil, planting seeds, fertilizing, making beds, and maintaining plants, including replanting, watering, and controlling pests and diseases. Pest and disease control with mechanically and chemically. Pest control using chemical insecticides are active ingredients: BPMC and Isoprotiolan to control pathogens. The dose of pesticide used is $100 \mathrm{ml}$ for one spray tank with a tank volume of 10 liters with application time in the morning. Potato harvesting is when more than $90 \%$ yellow in one plant plot, and all leaves have dried.

Observations include:

1. Plant height. Measure plant height from the base of the stem to the highest shoots.

2. The Number of Leaves. Count all leaves.

3. Leaf length

4. Leaf width

5. Weight tuber.

\section{Statistical Analysis}

This research applies a Single Factorial Experiment in Completely Random Design, where the factor is four levels of potato varieties, Granola (V1), Bliss (V2), Kentang Merah (V3) and Batang Hitam (V4), with 3 replications. Each experimental unit planted 100 plant populations with a spacing of $30 \mathrm{~cm} \times 70 \mathrm{~cm}$. Samples were observed as many as ten plants for each group of the experiment. The $\mathrm{F}$ test analyzed the data by $5 \%$ and continued by Duncan's New Multiple Range Test in $5 \%$.

\section{Results and Discussion}

\section{A. Results}

The results showed a significant effect in analysis variance between variety on the observed variables (Tables 1 and 2). 
Table 1. Potato plant height, leaf number, leaf length and leaf width Under The Stands of Immature Coffee Plants

\begin{tabular}{|c|c|c|c|c|}
\hline Varieties & $\begin{array}{l}\text { Plant Height } \\
(\mathrm{cm})\end{array}$ & Leaf Number & Leaf Length & Leaf Width \\
\hline Granola & $48.24 \mathrm{a}$ & $34,40 \mathrm{~b}$ & $13.26 \mathrm{a}$ & $14,60 \mathrm{a}$ \\
\hline Bliss & $39,66 \mathrm{~b}$ & $41,50 \mathrm{a}$ & $9,78 b$ & $10,15 b$ \\
\hline Kentang Merah & $38,48 b$ & $42,40 \mathrm{a}$ & $10,79 b$ & $11,98 b$ \\
\hline Batang Hitam & $40,60 \mathrm{~b}$ & $43,60 \mathrm{a}$ & $10,65 b$ & $11,60 \mathrm{~b}$ \\
\hline
\end{tabular}

Table 2. Effect of varieties on the growth of potato tubers

\begin{tabular}{lcccc}
\hline \multirow{2}{*}{ Genotype } & \multicolumn{2}{c}{ Tuber character } & \multicolumn{2}{c}{ Weight per tuber $(\mathrm{g})$} \\
\cline { 2 - 4 } & $2,96 \mathrm{a}$ & $2,26 \mathrm{a}$ & 0,68 & Maximum \\
\hline Granola & $2,05 \mathrm{c}$ & $1,80 \mathrm{c}$ & 0,61 & $35,88 \mathrm{a}$ \\
Bliss & $2,42 \mathrm{bc}$ & $1,76 \mathrm{c}$ & 0,49 & $28,31 \mathrm{~b}$ \\
Kentang Merah & $2,58 \mathrm{bc}$ & $2,05 \mathrm{~b}$ & 0,58 & $25,67 \mathrm{~b}$ \\
Batang Hitam & & & $34,95 \mathrm{a}$ \\
\hline
\end{tabular}

Information: The numbers followed by lowercase letters in the same column are not significantly different according to the DNMRT test at the level of $5 \%$.

\section{B. Discussion}

\section{Plant Height, Number of Leaves, Leaf Length,} and Leaf Width

The use of different varieties showed very significant different results on plant height parameters. The use of different varieties showed very significant different results on plant height parameters. Interactions between genetic and environmental factors affect plant growth due to differences in plant genotypes (Mursito, 2003). Interactions between genotypes and the environment cause morphological differences and crop production. Based on Table 1, the average height of potato plants from the four tested varieties is between $38.00-48.00 \mathrm{~cm}$. Granola (V1) produced the best average height increase of $4,24 \mathrm{~cm}$, significantly different from other varieties.

Based on plant height, potatoes are classified into five levels in UPOV (2004) characters, which are very short $(<44.0 \mathrm{~cm})$, short $(44.1-49.9 \mathrm{~cm})$, moderate $(50.0-54.9 \mathrm{~cm})$, height $(55.0-) 59.9 \mathrm{~cm})$, and very high $(>60.0 \mathrm{~cm})$. The potato varieties tested included in the concise classification were Bliss and Kentang Merah; and classification short was Granola and Batang Hitam. According to Hidayat (2014), potatoes that are good for cultivation have growth that is not too high, which is 44.0-54.9 cm. Therefore Granola and Kentang Merah have suitable criteria for planting.

Based on Table 1, the length and width of the leaves of the Batang Hitam varieties, namely 43.60 strands, $13.36 \mathrm{~cm}$, and $14.60 \mathrm{~cm}$, are significantly different from the granola varieties and are not significantly different from Bliss and Kentang Merah. According to Himma and Purwoko (2013) overlapping plant leaves will result in the plant not receiving light sun maximally and the process of photosynthesis takes place less than optimal resulting in growing plants become stunted.

The number of leaves increases when the plant height also increases and is also influenced by sunlight's intensity. Zelelew (2016) reports that higher plants will have more leaf production per plant and will affect photosynthate. Zulfitri (2015) also reports that increasing plant height is related to an increase in the number and size of cells. Plant height growth shows the activity of xylem formation and enlargement of growing cells.

\section{Tuber Length, Tuber Diameter, The Average Weight/Tuber}

Potato tubers function as a storage place for photosynthetic products in the form of carbohydrates, proteins, fats, vitamins, minerals, and water. Based on table 2, the Granola genotype shows the best results where the length of the tuber is $2.96 \mathrm{~cm}$, the diameter of the tuber is $2.26 \mathrm{~cm}$, and the maximum weight/tuber is 35.88 grams. The genotype of Kentang Merah and Batang Hitam shows that the length of the tuber is not much different, namely $2.42 \mathrm{~cm}$ and 2.58 $\mathrm{cm}$, but for the maximum weight/tuber Batang Hitam was higher than Kentang Merah, namely 34.95 grams, while Kentang Merah was 25.67 grams. The results of observations on the Bliss genotype showed that the tuber length was $2.05 \mathrm{~cm}$, the tuber diameter was 1.8 $\mathrm{cm}$, and the maximum weight/tuber was $28.31 \mathrm{gr}$. The rainfall and availability of nutrients affect tuber weight. Sutrisna and Surdianto (2014) research that potato plants require nutrients or macronutrients $\mathrm{N}, \mathrm{P}, \mathrm{K}, \mathrm{S}$, 
$\mathrm{Mg}, \mathrm{Ca}$ and micronutrients $\mathrm{Mo}, \mathrm{Cu}, \mathrm{B}, \mathrm{Zn}, \mathrm{Fe}$, and $\mathrm{Mn}$. Tuber weight also correlates with the vegetative growth of the plant. Arifin et al., 2014 stated that the higher the plants would produce more photosynthate so that more tuber formation and filling.

According to Urnemi (2002), giving different shade will affect light intensity, air temperature, soil temperature, air relative humidity, and soil moisture. The higher the shade level, the greater the soil humidity and air relative humidity, while the air temperature, soil temperature, and radiation intensity decreased. In low light conditions, plants try to maintain the photosynthesis process in low light intensity conditions. The condition of lack of light disrupts metabolism, so that the rate of photosynthesis and carbohydrate synthesis decreases, and results in decreased growth rate and plant productivity (Sopandie et al., 2003). Mohr and Schopfer (1995) stated that genetic traits determine plants' ability to adapt to the environment. Genetically, shade-tolerant plants have a higher ability to adapt to environmental changes. The adaptation of plants to shade depends on plants' ability to respond to low light conditions, namely by changing plant morphological and physiological properties (Sukarjo, 2004).

\section{Conclusions}

The diversity of varieties in this study was affected by plant genotypes. Genotype factors significantly affected the plant height, number of leaves, leaf length, tuber length, tuber diameter, and weight/tuber. The genotype of Granola shows the best character for all observation and produces the highest yields compared to the other genotypes. So it is advisable to cultivate varieties of granola for intercropping in Alahan Panjang, Solok Regency, West Sumatera.

\section{References}

[1] Arifin, M.S., A. Nugroho, and A. Suryanto. 2014. Study of Shoot Length and Weight of Potato Seed on Production of Potato (Solanum tuberosum L.) Granola Variety.

[2] Azmi N. 2013. Pengaruh naungan terhadap pertumbuhan dan produksi enam varietas tomat (Lycopersicon esculantum Mill.). Skripsi. Institut Pertanian Bogor. Bogor.

[3] Bahrun A.H. 2012. Kajian ekofisiologi tanaman semusim penyusun agroforestri pada beberapa zona agroklimat di DAS Ciliwung Hulu. Disertasi. Institut Pertanian Bogor. Bogor.

[4] Chozin M.A., Sopandie D., Sastrosumarjo S. dan Suwarno. 2000. Physiology and genetic of upland rice adaptation to shade. Final Report of Graduate Team 29 Research Grant, URGE Project. Directorate General of Higher Education, Ministry of Education and Culture.

[5] Elfarinsa. 2000. Adaptasi kedelai terhadap naungan : studi morfologi dan anatomi. Tesis. Institut Pertanian Bogor. Bogor.

[6] Hakim, L. 1999. Kajian komponen pengendalian terpadu penyakit layu bakteri pada kentang. Tesis. Sekolah Pasca Sarjana. Institut Pertanian Bogor. Bogor.

[7] Hidayat, Y.S. 2014. Karakterisasi morfologi beberapa genotipe kentang (Solanumtuberosum L.) yang dibudidayakan diIndonesia. Skripsi. Institut Pertanian Bogor. Bogor.

[8] Ministry of Agriculture. (2017). Potato Harvest Area by Province,2013-2017.http://www.pertanian.go.id/Data5tahun/ HortiATAP2017(.pdf)/L.\%20Panen\%20Kentang.pdf. Accessed on January 6th, 2020.

[9] Mohr, H, and Schopfer. P. 1995. Plant Physiology. Spinger. New York
[10] Pranoto A.H. 2011. Kajian agroekologi sistem agroforestri di Daerah Aliran Sungai Cianjur. Disertasi. Institut Pertanian Bogor. Bogor.

[11] Sastrahidayat, I.R. 2011. Tanaman Kentang dan Pengendalian Hama Penyakitnya. Universitas Brawijaya Press, Malang, ID.

[12] Sitangga, M. 2013. Response to potato seed production and growth. Thesis. Faculty of Agriculture. University of Nort Sumatera. Medan

[13] Sopandie D., Chozin M.A., Sastrosumarjo S., Juhaeti T. dan Sahardi. 2003. Toleransi padi gogo terhadap naungan. Hayati. $10(2): 71-75$.

[14] Sukarjo. 2004. Tolerance of some Curcuma spp to shade intensity. JIPI. 6(2):97-103.

[15] Sutrisna and Surdianto (2014). Study of NPK Fertilizer Formulas on Upland Potato Plantations in Lembang, West Java. J. Hort. 24(2):124-132.

[16] [UPOV] International Union for the Protection of New Varieties of Plants. 2004. Guidelines for the Conduct of Tests for Distinctness, Uniformity and Stability of Potato (Solanum tuberosum $\mathrm{L}$.)

[17] Urnemi. 2002. The effect of phosphorus fertilizers and herbal fertilizers on three levels of shade on the growth and standards of secondary metabolites of cumin leaves (Coleus amboinicus Lour.). Thesis. IPB. Bogor.

[18] Zalelew, D.Z., Sewa, L., Tesfai,T.K, and Biniam, M.G.2016. Effect of Potassium levels on growth and productivity of potato varieties. American Journal of Plant Science 7:1629-1638

[19] Zulfitri, I. 2015. Analysis of Varieties and Polybags on Growth and Yield of Chili (Capsicum annum L.) in Hydroponic System. Essay. Faculty of Agriculture, Bogor Agricultural University, Bogor. 